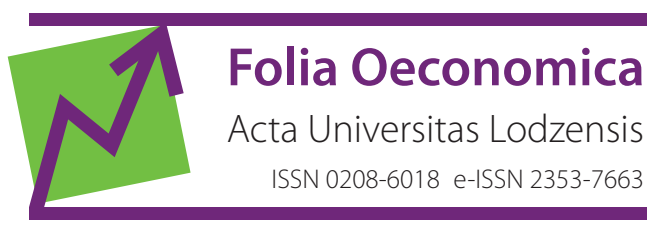

www.czasopisma.uni.lodz.pl/foe/

2(328) 2017

DOI: http://dx.doi.org/10.18778/0208-6018.328.11

\title{
Eugeniusz Kwiatkowski
}

Uniwersytet Łódzki, Wydział Ekonomiczno-Socjologiczny, Katedra Makroekonomii, ekwiatk@uni.lodz.pl

\section{Przemysław Włodarczyk}

Uniwersytet Łódzki, Wydział Ekonomiczno-Socjologiczny, Katedra Makroekonomii, pwlodarczyk@uni.lodz.pl

\section{Rodzaje umów o pracę a elastyczność zatrudnienia w nowych krajach członkowskich Unii Europejskiej w latach 2000-2014*}

Streszczenie: Przedmiotem artykułu jest elastyczność zatrudnienia w gospodarkach nowych krajów członkowskich Unii Europejskiej w latach 2000-2014. Szczególną uwagę poświęcono roli rodzaju umów o pracę w kształtowaniu tej elastyczności. Argumenty teoretyczne i obserwacje empiryczne pozwalają sformułować hipotezę o U-kształtnej zależności między udziałem pracujących na umowach na czas określony w ogólnej liczbie pracujących a elastycznością zatrudnienia. Należy również oczekiwać zwiększenia elastyczności płac i czasu pracy na skutek wzrostu udziału umów na czas określony. Wyniki estymacji modelu panelowego dla 13 nowych krajów członkowskich UE w latach 2000-2014 potwierdzają hipotezę o wpływie udziału umów na czas określony na elastyczność zatrudnienia. W szczególności rosnący udział tych umów powoduje spadek elastyczności zatrudnienia względem PKB i wzrost elastyczności zatrudnienia względem płac realnych i czasu pracy. Brak jest natomiast podstaw do potwierdzenia hipotezy o U-kształtnej zależności pomiędzy elastycznością zatrudnienia względem PKB a udziałem umów na czas określony.

Słowa kluczowe: rodzaje umów o pracę, elastyczność zatrudnienia, PKB, płace realne

JEL: J23, J41

* Badanie zrealizowane w ramach projektu Instytucje rynku pracy a sytuacja na rynkach pracy w krajach OECD w okresie globalnego kryzysu. Projekt sfinansowano ze środków Narodowego Centrum Nauki na podstawie decyzji numer DEC-2013/11/B/HS4/00684. 


\section{Wprowadzenie}

Gospodarki rynkowe podlegają różnorodnym oddziaływaniom, których źródła tkwią w nich samych bądź w ich otoczeniu zewnętrznym. Oddziaływania te mają różny charakter: koniunkturalny, trendów długofalowych, jednorazowych szoków o charakterze podażowym lub popytowym. Powodują one powstawanie nierównowag $\mathrm{w}$ gospodarce, $\mathrm{w}$ tym również na rynku pracy, inicjując jednocześnie odpowiednie procesy przystosowawcze. Procesy te wymagają pewnej elastyczności gospodarki, a więc jej zdolności do zmian istniejących stanów. Ze względu na to, że stopień elastyczności w poszczególnych obszarach systemu gospodarczego jest niejednakowy, zachodzące w nim procesy przystosowawcze, w tym również na rynku pracy, mogą mieć zróżnicowany charakter.

Przedmiotem artykułu jest elastyczność zatrudnienia w nowych krajach członkowskich Unii Europejskiej: w Bułgarii, Chorwacji, na Cyprze, w Czechach, Estonii, Litwie, Łotwie, na Malcie, w Polsce, Rumunii, Słowacji, Słowenii i na Węgrzech w latach 2000-2014. Szczególną uwagę poświęcono roli rodzaju umów o pracę w kształtowaniu tej elastyczności.

Artykuł rozpoczyna się od rozważań o charakterze teoretycznym, dotyczących roli elastyczności rynku pracy w głównych koncepcjach teoretycznych w ekonomii (część 2). W części 3 analizy koncentrują się na prezentacji hipotez dotyczących charakteru i mechanizmów dostosowawczych na rynku pracy. W części 4 dokonujemy przeglądu dotychczasowych wyników badań empirycznych dotyczących wpływu rodzaju umów o pracę na elastyczność zatrudnienia. Przedmiotem analizy w części 5 są tendencje zmian zatrudnienia oraz udziału umów na czas określony w ogólnej liczbie pracujących w nowych krajach członkowskich Unii Europejskiej w latach 2000-2014. W części 6 zaprezentowano natomiast wyniki analizy ekonometrycznej wpływu rodzaju umów na elastyczność zatrudnienia w tych krajach. Ważniejsze wnioski przedstawiono w części 7.

\section{Istota i znaczenie elastyczności zatrudnienia dla procesów dostosowawczych w gospodarce}

Elastyczność zatrudnienia jest elementem składowym szerszego pojęcia, jakim jest elastyczność rynku pracy. Elastyczność rynku pracy oznacza jego zdolność do szybkich przystosowań do zmian warunków rynkowych i technologii (Adnett, 1996: 12). Zgodnie z przyjętą w literaturze ekonomicznej klasyfikacją na elastyczność rynku pracy składają się: elastyczność zatrudnienia (popytu na pracę), elastyczność płac, elastyczność czasu pracy i elastyczność podaży pracy (Kwiatkowski, 2006: 285-286; Rogut, 2008: 35).W literaturze ekonomicznej znaleźć również 
można szersze ujęcie, zgodnie z którym elastyczność zatrudnienia to zdolność gospodarki do szybkiego i bezzakłóceniowego osiągania stanu równowagi oczyszczającej rynek pracy (Solow, 1998).

Znaczenie elastyczności rynku pracy dla kształtowania procesów gospodarczych podkreślano od dawna w różnych teoriach ekonomicznych, a w szczególności w teoriach rynku pracy. Początkowo zdecydowanie większy nacisk kładziono na rolę elastyczności płac $\mathrm{w}$ przywracaniu równowagi pomiędzy popytem na pracę i podażą pracy. W bardziej współczesnych ujęciach zwrócono większą uwagę na rolę elastyczności zatrudnienia oraz elastyczności czasu pracy w kształtowaniu procesów przystosowawczych do szoków oddziałujących na gospodarkę, a w szczególności w kształtowaniu charakteru i długości trwania tych procesów.

Ekonomiści klasyczni i neoklasyczni zwracali uwagę na fakt, iż niedopasowania popytu i podaży pracy wywołują zmiany wysokości płac realnych, realokację siły roboczej oraz zmiany popytu na pracę i podaży pracy, które prowadzą do równowagi na rynku pracy (Smith, 1954, t. I: 101-104 i 435; Pigou, 1933: 252). Warunkiem koniecznym pełnego zatrudnienia jest więc elastyczność płac, popytu na pracę i podaży pracy.

Keynes podważył wiarę neoklasyków w skuteczne działanie mechanizmów rynkowych w gospodarce, a w szczególności na rynku pracy. Jego zdaniem nawet w pełni elastyczne płace nie są w stanie zapewnić pełnego zatrudnienia. Mamy w teorii Keynesa myśl o zatrudnieniu dostosowującym się do poziomu produkcji (elastycznym względem produkcji) (Keynes, 1985: 311-316).

M. Friedman zwrócił uwagę na istnienie bezrobocia naturalnego, powstającego w gospodarce, w której rzeczywiste warunki funkcjonowania odbiegają od doskonałej konkurencji (Friedman, 1975: 271). W myśl jego koncepcji ograniczenia elastyczności gospodarki i rynków pracy implikują istnienie naturalnego bezrobocia. Teoria bezrobocia naturalnego wskazuje, że poprawa elastyczności rynku pracy odgrywa ważną rolę w redukcji tego typu bezrobocia.

Zgodnie z teorią NAIRU, bezrobocie równowagi zależy od szeregu czynników realnych związanych z funkcjonowaniem rynku pracy. Wśród tych czynników znajdujemy również takie, które dotyczą elastyczności rynku pracy, a mianowicie: rozwiązania w zakresie zasiłków dla bezrobotnych (Layard, 1986: 45), ustawodawstwo określające stopień ochrony stosunku pracy (Layard, Nickell, Jackman, 1991: 74), wysokość postulatów płacowych i siła związków zawodowych, niedopasowania strukturalne podaży pracy i popytu na pracę w różnych przekrojach, a w szczególności w przekroju płci, zawodów, wykształcenia i regionów (Layard, Nickell, Jackman, 1991: 285-335) oraz stopień mobilności siły roboczej, zwłaszcza mobilności zawodowej, kwalifikacyjnej i przestrzennej.

Problem elastyczności rynków pracy podnoszony jest również w teoriach opisujących procesy przystosowawcze w gospodarce po wystąpieniu szoków ogólnej aktywności gospodarczej, rozwijających się w latach osiemdziesiątych i dziewięć- 
dziesiątych XX wieku. Traktuje się w nich elastyczność rynków pracy jako ważny czynnik wpływający na charakter i szybkość procesów przystosowawczych (por. Smith, 2003: 47-73; Cahuc, Zylberberg, 2004: 193-214; Bosworth, Dawkins, Stromback, 1996: 124-127, 194-196).

W przypadku negatywnego szoku popytowego pojawiają się procesy przystosowawcze $\mathrm{w}$ gospodarce, $\mathrm{w}$ tym $\mathrm{m}$. in. na rynkach produktów i pracy (por. Tsoulfidis, 2010: 363-380). Negatywny szok popytowy wywoływać może dostosowania cenowe i płacowe, likwidując powstałe nierównowagi. Wtedy nie dochodzi w zasadzie do spadku produkcji, zaś pojawiające się nierównowagi na rynku pracy są szybko likwidowane przez dostosowania płac realnych. Ujęcie to nawiązuje do tradycji neoklasycznej. Procesy dostosowawcze wyglądają inaczej w koncepcjach nawiązujących do tradycji keynesistowskiej. Na gruncie tej tradycji teoretycznej, zwłaszcza w ekonomii nowego keynesizmu, rozwinięto szereg koncepcji uzasadniających sztywność cen i płac (m. in. koncepcje kosztów menu, kontraktów implicite, płac efektywnościowych czy też insider-outsider). Podkreśla się w niej, że procesy dostosowawcze polegają przede wszystkim na dostosowaniach ilościowych, co w przypadku negatywnego szoku popytowego znajduje wyraz w spadku produkcji oraz zatrudnienia, względnie zmniejszeniu czasu pracy (por. Smith, 2003: 47-73; Cahuc, Zylberberg, 2004: 193-214; Bosworth, Dawkins, Stromback, 1996: 124-127, 194-196).

\section{Wpływ rodzaju umów o pracę na elastyczność rynku pracy - hipotezy teoretyczne}

Nacisk kładziony we współczesnych teoriach ekonomicznych na rolę elastyczności rynku pracy w szybkim przywracaniu równowagi rynkowej po wystąpieniu szoków o charakterze makroekonomicznym sprawił, że w latach osiemdziesiątych i dziewięćdziesiątych XX w. w większości krajów rozwiniętych podejmowano próby wprowadzenia rozwiązań systemowych ukierunkowanych na zwiększenie elastyczności zatrudnienia, płac i czasu pracy. W szczególności cele te próbowano osiągnąć poprzez postępującą deregulację w sferze prawnej ochrony zatrudnienia $^{1}$ (EPL) oraz popularyzację niestandardowych (elastycznych, nietypowych) form zatrudnienia.

Pojęcie niestandardowych form zatrudnienia odnosi się do wszelkich form stosunku pracy innych niż zatrudnienie w oparciu o umowę o pracę na czas nieokreślony (Kryńska, 2001: 94). Możemy do nich zaliczyć: pracę w oparciu o ter-

1 Tematyka wpływu zmian w zakresie prawnej ochrony zatrudnienia na procesy dostosowawcze na rynku pracy była przedmiotem zainteresowania autorów we wcześniejszych opracowaniach: Kwiatkowski, Włodarczyk (2012); Kwiatkowski, Włodarczyk (2014). 
minowe umowy o pracę (umowy o pracę na czas określony), pracę tymczasową, pracę $\mathrm{w}$ niepełnym wymiarze czasu pracy, zatrudnienie na podstawie umowy cywilnoprawnej, samozatrudnienie, kontraktowanie pracy, telepracę, pracę w domu, wypożyczanie pracowników, dzielenie pracy, pracę na wezwanie i pracę na telefon oraz pracę w nienormowanym czasie pracy (Kryńska, 2001: 94-97; Wincenciak, Zys, 2013: 119).

Wykorzystanie niestandardowych form zatrudnienia przynosi liczne korzyści o charakterze ekonomicznym i społecznym, które pojawiają się zarówno po stronie pracodawców, jak również pracowników. Z punktu widzenia pracodawców pozwalają one przede wszystkim na zwiększenie elastyczności przedsiębiorstwa i zdolności dostosowawczej do zmian otoczenia ekonomicznego przedsiębiorstwa poprzez wzrost swobody dopasowań poziomu i czasu zatrudnienia do bieżących potrzeb, a także na obniżenie kosztów zatrudnienia. Z punktu widzenia pracowników praktyki te prowadzą do większej swobody w zakresie doboru charakteru i liczby realizowanych zleceń, organizacji procesu pracy oraz pozwalają na podjęcie pracy w sytuacji, gdy znalezienie zatrudnienia w tradycyjnej formie jest niemożliwe. Ze społecznego punktu widzenia pozwala to znacząco ograniczyć negatywne skutki bezrobocia. Wykorzystanie niestandardowych form zatrudnienia może jednak również prowadzić do pojawienia się zagrożeń, które będą w konsekwencji prowadziły do wzrostu poziomu niezadowolenia społecznego. Elastyczne formy zatrudnienia cechujące się z reguły niższym poziomem prawnej ochrony zatrudnienia (EPL) zwiększają rotację pracowników, co może utrudniać budowanie relacji opartych na lojalności i poszanowaniu wzajemnych interesów pracowników i pracodawców. Z punktu widzenia pracowników szczególnie niekorzystna jest natomiast perspektywa znalezienia się $\mathrm{w}$,pułapce nietypowych form zatrudnienia". O ile niestandardowe formy zatrudnienia mogą bowiem stanowić znaczącą pomoc dla pracowników, gdy są one przejściowym etapem kariery zawodowej, o tyle trwałe zatrudnienie w tym segmencie rynku pracy, cechującym się znacznie słabszą ochroną prawną stosunku pracy, przekłada się na utratę pewności zatrudnienia, gorszy dostęp do możliwości rozwoju zawodowego, niższe zarobki oraz niższy standard życia i bezpieczeństwa socjalnego (Jeleniewska, Chrościelewski, Opieka, 2008: 153-166; Wincenciak, Zys, 2013: 119-120).

W dalszych analizach nasza uwaga będzie się koncentrowała na roli umów na czas określony w kształtowaniu elastyczności zatrudnienia. Umowy na czas określony są bowiem najpopularniejszą spośród niestandardowych form zatrudnienia stosowanych we współczesnych gospodarkach (por. np. Cazes, de Laiglesia, 2014).

Struktura zatrudnienia według rodzaju umów o pracę, tj. umów na czas określony i nieokreślony odgrywa istotną rolę w kształtowaniu elastyczności zatrudnienia. Pracownicy preferują zatrudnienie w oparciu o umowy na czas nieokreślony, gdyż zapewniają im one większą stabilność zatrudnienia i dochodów. Umowy takie zapewniają zdecydowanie wyższy stopień ochrony stosunku pracy, gdyż zazwy- 
czaj w ich przypadku stosunkowo długie są okresy wypowiedzenia pracy, a ponadto zwolnienia pracowników zatrudnionych na podstawie takich umów wiążą się zwykle z koniecznością wypłaty relatywnie wysokich odpraw pieniężnych. Nic więc dziwnego, że pracodawcy starają się minimalizować zwolnienia pracowników zatrudnionych na podstawie umów na czas nieokreślony. Sytuacja wygląda inaczej w przypadku zatrudnienia na czas określony. Poziom ochrony stosunku pracy jest wówczas znacznie niższy (znacznie krótsze są okresy wypowiedzenia, zaś odprawy pieniężne przy zwolnieniach w ogóle nie występują). Ryzyko wahań zatrudnienia i dochodów przeniesione jest wówczas prawie w całości na pracowników. Natomiast dla pracodawców ten rodzaj umów o pracę przynosi szereg korzyści, w szczególności korzyść związaną z możliwością dopasowania liczby zatrudnionych pracowników do warunków ekonomicznych. Dlatego pracodawcy są zainteresowani zatrudnianiem pracowników w ramach umów na czas określony (Bednarski, 2012: 37-43).

Argumenty teoretyczne i obserwacje empiryczne pozwalają sformułować hipotezę o U-kształtnej zależności między udziałem pracujących na umowach na czas określony w ogólnej liczbie pracujących a elastycznością zatrudnienia. Hipotezę tę można uzasadnić następująco. Przy wysokim udziale pracujących na czas określony elastyczność zatrudnienia może być dosyć wysoka ze względu na niski poziom prawnej ochrony zatrudnienia i łatwość zwolnień pracowników w okresach pogorszenia koniunktury. Spadek udziału pracujących na umowach na czas określony powinien zmniejszyć elastyczność zatrudnienia z powodu wzrostu ochrony stosunku pracy i wyższych kosztów zwolnień z pracy. Ale prawidłowość ta ma prawdopodobnie swoje granice. Przy zbyt niskim udziale pracujących na umowach na czas określony i niemożności jakichkolwiek dopasowań liczby pracujących do warunków ekonomicznych mogą pojawić się dodatkowe koszty nieracjonalnej alokacji siły roboczej w przedsiębiorstwach, powodujące negatywne konsekwencje dla zysków przedsiębiorstw i ich rozmiarów popytu na pracę, podnosząc w rezultacie elastyczność zatrudnienia w okresie pogorszenia koniunktury (tzn. zwiększając spadek zatrudnienia w tym okresie) (por. Malul, Rosenboim, Shavit, Yerba, 2011). Możemy zatem oczekiwać istnienia U-kształtnej zależności pomiędzy udziałem liczby umów na czas określony w liczbie umów ogółem a elastycznością popytu na pracę względem rozmiarów produkcji.

Udział liczby pracujących na umowach na czas określony w liczbie umów o pracę ogółem ma również wpływ na obserwowane w danej gospodarce elastyczności płac i czasu pracy. Im większy jest udział umów na czas określony, tym większe możliwości dostosowywania płac i czasu pracy przez pracodawców. W przypadku umów na czas nieokreślony zmiana poziomu płac lub czasu pracy w przedsiębiorstwie wymaga podjęcia negocjacji z pracownikami i jest możliwa jedynie pod warunkiem osiągnięcia porozumienia. W negocjacjach pracowników tych reprezentują zwykle związki zawodowe, których głównym celem jest 
ochrona interesów pracowniczych. Jednocześnie z faktu, iż zrzeszają one znaczną część pracowników przedsiębiorstwa, wynika ich siła przetargowa. Brak porozumienia uniemożliwia bowiem pracodawcy podjęcie produkcji. Siła przetargowa związków zawodowych sprawia, że poziom płac wyznaczony w wyniku takich negocjacji jest wyższy niż w przypadku, gdy ustalany jest on na w pełni konkurencyjnym rynku pracy, a nadwyżka jest proporcjonalna do siły przetargowej związków. Możliwości dostosowawcze przedsiębiorstwa w zakresie zmian wysokości płac są tym samym ograniczone. Podobnie w przypadku negocjacji dotyczących czasu pracy - związki zawodowe mogą skutecznie ograniczyć skalę wprowadzanych zmian, gdyż w razie nieosiągnięcia porozumienia niemożliwe będzie podjęcie produkcji przez analizowane przedsiębiorstwo. Skutkuje to ograniczonymi możliwościami dostosowawczymi przedsiębiorstwa w zakresie czasu pracy (Boeri, van Ours, 2011: 90-93).

W przypadku gdy pracownicy są zatrudniani na czas określony, pracodawca może w łatwy sposób dokonać zmiany wynagrodzenia przy okazji podpisywania nowego kontraktu. Sprawia to, że przeciętny okres obowiązywania wynagrodzeń w gospodarce zmniejsza się i mniejsza jest sztywność nominalna płac. Podobny mechanizm działa, gdy pracodawca dąży do zmniejszenia czasu pracy. W przypadku niektórych elastycznych form zatrudnienia, takich jak: dzielenie pracy, praca na wezwanie czy praca na telefon ograniczenie czasu pracy nie wymaga nawet podpisania kolejnej umowy. Wzrost udziału elastycznych form zatrudnienia, w tym w szczególności zatrudnienia na czas określony w zatrudnieniu ogółem, prowadzi zatem do wzrostu elastyczności czasu pracy.

Jak wynika z powyższych rozważań, wzrost udziału liczby pracujących na czas określony prowadzi do większej elastyczność płac i czasu pracy, co zgodnie z opisywanym w teorii zjawiskiem wymienności charakteru dopasowań umożliwia ograniczenie dostosowań ilościowych zatrudnienia i przekłada się na mniejszą elastyczność zatrudnienia względem rozmiarów produkcji wytworzonej w danej gospodarce. Większe możliwości dostosowawcze pracodawców w zakresie czasu pracy i płac prowadzą jednak również w sposób naturalny do powstania skutków ubocznych w postaci większej wrażliwości popytu na pracę na zmiany tych dwóch czynników.

\section{Przegląd wyników dotychczasowych badań empirycznych}

Kwestia wpływu rosnącego udziału niestandardowych form zatrudnienia w liczbie umów ogółem na sytuację panującą na rynku pracy była w przeszłości przedmiotem analiz empirycznych, choć należy zauważyć, że liczba opracowań w tym 
zakresie jest znacząco niższa niż w przypadku innych czynników o charakterze instytucjonalnym, jak na przykład EPL, płace minimalne czy poziom uzwiązkowienia i negocjacje zbiorowe. Poniżej przedstawiony został przegląd najważniejszych wyników badań w tym zakresie.

Modele opisujące wpływ umów na czas określony na sytuację na rynku pracy możemy podzielić na dwie zasadnicze grupy. Do pierwszej z nich należą prace, w których analizowany jest wpływ umów na czas określony na zmienne zasobowe rynku pracy, takie jak zatrudnienie, bezrobocie, płace realne, czas pracy. W drugiej znajdują się badania dotyczące wpływu tych umów na kształtowanie się zmiennych strumieniowych rynku pracy, w tym przede wszystkim stóp napływu do i odpływu z zasobu bezrobocia oraz rotacji pracowników i miejsc pracy.

Wśród tradycyjnych modeli zorientowanych na analizę wpływu elastycznych form zatrudnienia na zmienne zasobowe rynku pracy na pierwszy plan wybijają się w ostatnim czasie te, które wykorzystują dane panelowe pochodzące z przedsiębiorstw. Aguirregabiria i Allonso-Borgero (2014) wykazali, że przeprowadzona w Hiszpanii w 1984 roku reforma rynku pracy, która umożliwiła wykorzystywanie na szeroką skalę zatrudnienia na czas określony, doprowadziła do wzrostu popytu na pracę o ok. 3,5\%. Jednocześnie spowodowała znaczną substytucję umów na czas nieokreślony umowami na czas określony. Efekt ten oszacowano na około 10\% rozmiarów dotychczasowego zatrudnienia na czas nieokreślony. Badanie wykazało, że zbliżone efekty w zakresie rozmiarów zatrudnienia, przy jednoczesnym wzroście wydajności pracy można uzyskać, wprowadzając bardziej liberalne rozwiązania z zakresu ochrony stosunku pracy w odniesieniu do umów na czas nieokreślony. Zbliżone wyniki oparte na danych agregatowych dotyczących sektorów hiszpańskiej gospodarki w latach 1987-2000 znajdujemy również w pracy Ortegi i Marchante'a (2010).

Goux, Mourin i Pauchet (2001), Dhyne i Mahy (2009) oraz Pfeiffer (2009) analizowali wykorzystanie umów na czas określony w perspektywie reakcji na oczekiwane i nieoczekiwane szoki popytowe. Ich wyniki wskazują, iż umowy na czas określony są wykorzystywane przez przedsiębiorstwa przede wszystkim w przypadku konieczności dostosowania zatrudnienia do nieoczekiwanych zmian aktywności gospodarczej, podczas gdy w przypadku oczekiwanych wahań popytu na produkty zmiany dotyczą zatrudnionych na umowach na czas nieokreślony. Fluktuacje liczby pracujących na umowach na czas określony pozwalają tym samym ograniczyć wahania zatrudnienia pracowników pracujących na stałe.

Interesujących wyników dotyczących funkcjonowania mechanizmów dostosowawczych na rynku pracy dostarczają również badania, w których wykorzystane zostały modele poszukiwań i dopasowań. Bentolila i in. (2012) przeprowadzili analizę dostosowań rozmiarów bezrobocia we Francji i w Hiszpanii w okresie światowego kryzysu gospodarczego, stwierdzając, że bardziej liberalne ustawodawstwo regulujące pracę na czas określony, które obowiązywało w tym okre- 
sie w Hiszpanii, prowadziło do zdecydowanie większych spadków zatrudnienia i wzrostów bezrobocia w następstwie negatywnych szoków ekonomicznych. Według wspomnianych autorów różnice w poziomie prawnej ochrony zatrudnienia kontraktów na czas określony w tych krajach tłumaczą nawet $45 \%$ różnic w reakcji popytu na pracę. Sugerują oni tym samym, że bardzo wysoka elastyczność zatrudnienia może, w warunkach negatywnego szoku ekonomicznego, prowadzić do nadmiernej zmienności zatrudnienia i bezrobocia oraz powodować negatywne konsekwencje w skali całej gospodarki. Wyniki wskazujące na większą zmienność cykliczną zatrudnienia w sytuacji, gdy rośnie dostępność umów na czas określony, uzyskali również Benito i Hernando (2008). Również Blanchard i Landier (2002) doszli do wniosku, że jeśli kontrakty na czas określony są nadużywane i nie prowadzą do zatrudnienia na czas nieokreślony, to ułatwienia w ich wykorzystaniu mogą prowadzić do nadmiernej zmienności zatrudnienia i wysokiego poziomu bezrobocia w skali całej gospodarki.

Wyniki badań empirycznych wskazują, iż postępująca liberalizacja regulacji w zakresie ochrony zatrudnienia, zwiększająca możliwości wykorzystania umów na czas określony, prowadzi do większej elastyczności płac (np.: Benito, Hernando, 2008; van Lancker, 2012). Jak wskazują Böheim i Zweimüller (2013), wzrost elastyczności płac jest między innymi wynikiem osłabienia siły przetargowej związków zawodowych w przedsiębiorstwach o rosnącym udziale pracowników tymczasowych. Bardziej pesymistycznych szacunków dotyczących wpływu rosnącego udziału zatrudnienia na czas określony na elastyczność płac realnych dostarcza praca Bentoliliego i Dolado (1994), którzy wskazują, iż efekty obserwowanych zmian dotyczyły jedynie tych pracowników, którzy otrzymywali płace progowe, co nie przekładało się na wynagrodzenia pracowników zatrudnionych na czas nieokreślony. Gebel (2009) i van Lancker (2012) wskazują natomiast na negatywne skutki związane ze wzrostem zatrudnienia tymczasowego w postaci rosnącej segmentacji rynków pracy i luki płacowej. Zjawisko to dotyka w szczególności ludzi młodych, osoby starsze oraz kobiety.

Podsumowując powyższe rozważania, należy zauważyć, że przytoczone analizy empiryczne przynajmniej częściowo potwierdzają hipotezy wysunięte na podstawie rozważań teoretycznych przedstawionych w poprzedniej części niniejszej pracy, w szczególności jeśli chodzi o istnienie U-kształtnej zależności pomiędzy elastycznością zatrudnienia a udziałem umów na czas określony w liczbie umów o pracę ogółem oraz związku pomiędzy udziałem umów na czas określony w liczbie umów ogółem a elastycznością płac. Stosunkowo niewiele informacji uzyskujemy natomiast na temat wpływu nietypowych form zatrudnienia na elastyczność czasu pracy. 


\section{Tendencje zmian form zatrudnienia a elastyczność zatrudnienia w latach 2000-2014}

Przyjrzyjmy się bliżej tendencjom zmian zatrudnienia oraz udziału umów na czas określony w liczbie umów o pracę ogółem w nowych krajach członkowskich (NKC) na tle zmian obserwowanych w całej Unii Europejskiej. W analizach wykorzystano dane roczne dla 28 krajów Unii Europejskiej z lat 2000-2014, pochodzące $\mathrm{z}$ internetowej bazy danych Eurostat ${ }^{2}$ oraz bazy danych LABORSTA opracowywanej przez Międzynarodową Organizację Pracy (ILO) ${ }^{3}$. Ze względu na stosunkowo dużą liczbę analizowanych szeregów czasowych część danych prezentowana jest w przekroju grup krajów (NKC - 13 krajów, EU 15 oraz strefy euro). Przystępując do analizy, należy pamiętać, iż grupy te nie są rozłączne, ale częściowo się pokrywają.

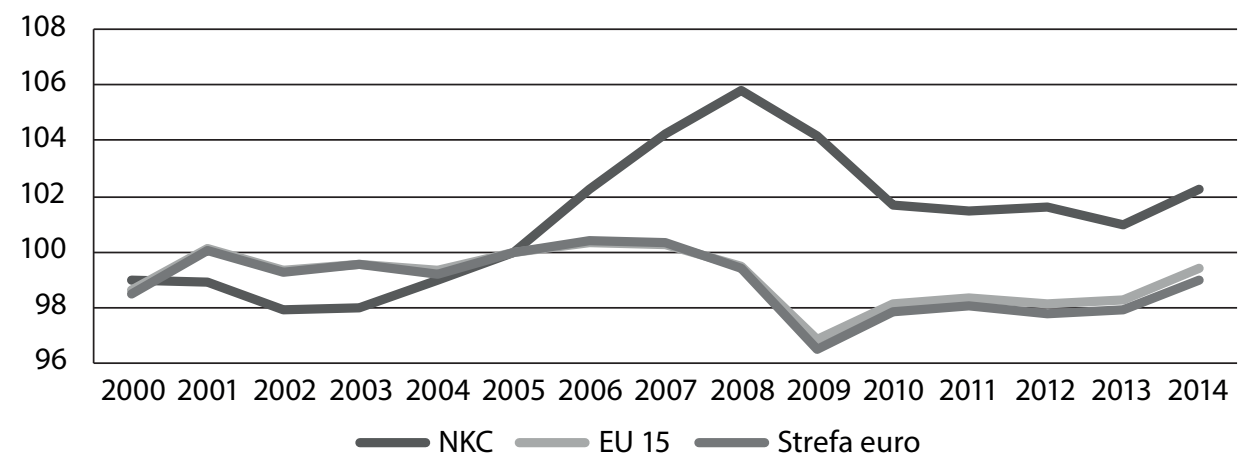

Wykres 1. Dynamika zmian zatrudnienia w krajach Unii Europejskiej w latach 2000-2014 $(2005=100)$

Źródło: Internetowe bazy danych Eurostat oraz ILO

Na wykresie 1 przedstawiono zmiany zatrudnienia w analizowanych grupach krajów w latach 2000-2014. W badanym okresie zatrudnienie w NKC wykazywało zmienne tendencje. W latach 2000-2003 obserwowano jego spadki, podczas gdy w krajach starej Unii Europejskiej mieliśmy do czynienia jedynie ze stabilizacją poziomu zatrudnienia. Tendencja taka mogła być związana $\mathrm{z}$ faktem, iż w okresie poprzedzającym przyjęcie pierwszej i największej grupy NKC do Unii miały one ograniczony dostęp do funduszy unijnych. Lata 2004-2008 to okres dynamicznego rozwoju NKC związanego z akcesją kolejnych krajów. W tym czasie obserwowano w nich szybki wzrost poziomu zatrudnienia. Średnie roczne tempo wzrostu

\footnotetext{
2 http://ec.europa.eu/eurostat/data/database [dostęp: 4.05.2015].

${ }^{3}$ http://www.ilo.org/ilostat [dostęp: 13.05.2015].
} 
zatrudnienia w tym okresie wyniosło ok. 1,55\%, podczas gdy w tym samym czasie średnie roczne tempo wzrostu zatrudnienia w krajach UE 15 wyniosło $-0,02 \%$, a największy przyrost zatrudnienia w roku 2005 wyniósł zaledwie $0,65 \%$.

W latach 2007-2010 we wszystkich krajach Unii Europejskiej obserwowano spadki rozmiarów zatrudnienie wywołane przez światowy kryzys gospodarczy. Spadki te były nieznacznie głębsze w dynamicznych gospodarkach NKC niż w krajach tzw. starej Unii Europejskiej. Średnie tempo spadku zatrudnienia w tym okresie wyniosło 1,96\% w NKC i 1,70\% w UE 15. Głębokie spadki zatrudnienia w okresie światowego kryzysu gospodarczego odnotowano również w krajach strefy euro. Średnie tempo spadku zatrudnienia w tej grupie krajów wyniosło $1,95 \%$. Było to przede wszystkim wynikiem wystąpienia w niektórych państwach członkowskich strefy euro kryzysów fiskalnych spowodowanych nadmiernym zadłużeniem, które wymusiły wdrożenie szeroko zakrojonych planów oszczędnościowych w niekorzystnej fazie cyklu koniunkturalnego. W największym stopniu problemy te dotknęły gospodarek Grecji, Irlandii, Hiszpanii, Portugalii i Włoch. Konieczność naprawy finansów publicznych tych krajów sprawiła, że odnotowywały one niższą dynamikę zatrudnienia również w okresie poprawy koniunktury po kryzysie (w latach 2010-2014). Stosunkowo wysokie spadki zatrudnienia w NKC w okresie kryzysu mogą świadczyć o większej skłonności pracodawców do przeprowadzania dostosowań ilościowych zatrudnienia w obliczu niekorzystnych zmian koniunktury gospodarczej, niż ma to miejsce w przypadku krajów UE 15. Wydaje się, iż zjawisko to można tłumaczyć między innymi niższym poziomem ochrony zatrudnienia oraz mniejszą siłą przetargową związków zawodowych w tej grupie krajów.

Lata 2011-2013 były okresem pokryzysowej stagnacji we wszystkich analizowanych grupach krajów. W roku 2014 odnotowano natomiast pierwszy od 2007 wyraźny wzrost koniunktury gospodarczej i wzrosty rozmiarów zatrudnienia. Najwyższą dynamikę wzrostu wykazywały NKC, w których rozmiary zatrudnienia zwiększyły się o 1,23\% w porównaniu z 1,09\% w krajach UE15 i 1,08\% w krajach strefy euro.

Miarą oddającą stopień cyklicznej zmienności zatrudnienia jest współczynnik zmienności zatrudnienia, którego wartości dla NKC w latach 2000-2014 przedstawiono w tabeli 1 . Wynika $\mathrm{z}$ niej, iż największe wahania zatrudnienia $\mathrm{w}$ analizowanym okresie obserwowano na Cyprze i Malcie. Wysokie współczynniki zmienności występowały również w przypadku Łotwy, Bułgarii i Polski. Najmniejszą zmiennością zatrudnienia w analizowanym okresie cechowały się natomiast gospodarki Czech, Węgier i Słowenii. Należy zauważyć, iż w przypadku większości krajów NKC (10 z 13 krajów) współczynniki zmienności kształtowały się na poziomie $4 \%$ i wyższym. Dla porównania, w tym samym okresie współczynniki zmienności w krajach starej Unii Europejskiej były zdecydowanie niższe i wynosiły: 3,2\% w Niemczech, 3,1\% we Francji i 2,4\% w Wielkiej Brytanii. 
Tabela 1. Współczynnik zmienności zatrudnienia w NKC w latach 2000-2014

\begin{tabular}{|l|c|}
\hline \multicolumn{1}{|c|}{ Kraj } & Współczynnik zmienności zatrudnienia (\%) \\
\hline Cypr & 8,7 \\
\hline Malta & 6,7 \\
\hline Łotwa & 6,4 \\
\hline Bułgaria & 6,1 \\
\hline Polska & 5,7 \\
\hline Chorwacja & 5,5 \\
\hline Litwa & 5,4 \\
\hline Rumunia & 4,9 \\
\hline Słowacja & 4,5 \\
\hline Estonia & 4,0 \\
\hline Słowenia & 3,3 \\
\hline Węgry & 2,3 \\
\hline Czechy & 2,1 \\
\hline
\end{tabular}

Źródło: obliczenia własne

Lata osiemdziesiąte i dziewięćdziesiąte XX w. były okresem znacznego wzrostu popularności niestandardowych form zatrudnienia, w tym między innymi zatrudnienia na umowach na czas określony oraz pracy tymczasowej. Tendencja ta była wynikiem pojawienia się licznych teorii ekonomicznych, które podkreślały znaczenie elastyczności płac i czasu pracy dla charakteru i szybkości procesów dostosowawczych na rynku pracy. Wskazywały one, iż większa elastyczność rynku pracy sprzyja ograniczeniu rozmiarów dostosowań ilościowych zatrudnienia.

W latach 2000-2014 w większości krajów Unii Europejskiej podejmowano wysiłki zmierzające do dalszej deregulacji rynku pracy, która sprzyjała wzrostowi popularności niestandardowych form zatrudnienia, w tym zwiększeniu udziału umów o pracę na czas określony w liczbie umów o pracę ogółem. Podobne tendencje obserwowano również w NKC (wykres 2). W analizowanym okresie udział umów na czas określony wzrósł w 8 krajach z 13 tej grupy. Jego spadki zaobserwowano jedynie na Litwie, Łotwie i w Rumunii. W przypadku Bułgarii i Chorwacji nie możemy ocenić tendencji w tym zakresie ze względu na brak odpowiednich danych.

W roku 2014 krajami o najwyższym udziale umów na czas określony były: Polska (28,3\%), Cypr (19\%) i Chorwacja (16,9\%). W tym samym roku najniższy udział umów na czas określony odnotowano w Rumunii (1,5\%), na Litwie $(2,8 \%)$ oraz w Estonii (3,1\%). Należy zauważyć, że podobne zróżnicowanie, jeśli chodzi o udział umów na czas określony, widzimy również w krajach UE 15, wśród których są zarówno kraje o bardzo wysokim udziale tych umów, jak np.: Hiszpania (24\%), Portugalia (21,9\%) czy Holandia (21,4\%), jak również kraje o względnie niskimi ich udziale, takie jak: Wielka Brytania $(6,3 \%)$, Belgia $(8,6 \%)$ czy Dania 
(8,6\%). Udział umów na czas określony w największych gospodarkach „starej Unii" wynosi 13,1\% w Niemczech i 15,7\% we Francji.

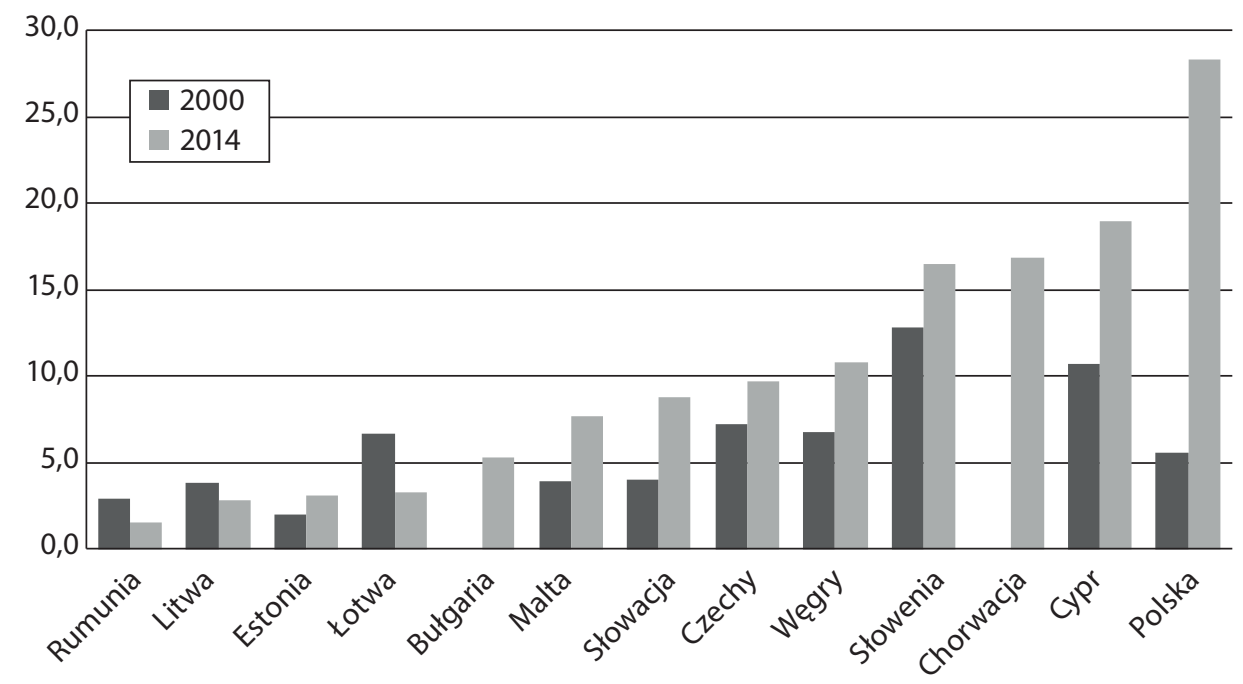

Wykres 2. Udział umów o pracę na czas określony w liczbie umów ogółem w latach 2000 i 2014

Źródło: internetowa baza danych Eurostat

Porównując ze sobą dane dotyczące cyklicznej zmienności zatrudnienia i udziału umów na czas określony w grupie NKC, stwierdzamy, że wśród krajów charakteryzujących się największą zmiennością poziomu zatrudnienia (tab. 1) znalazły się zarówno kraje o najwyższych, jak i najniższych udziałach umów na czas określony w liczbie umów o pracę ogółem. Krajami, które charakteryzowała wysoka wartość obu tych charakterystyk, były: Polska, Cypr i Chorwacja. Krajami o stosunkowo niskim udziale umów na czas określony i wysokiej zmienności zatrudnienia były zaś: Łotwa, Bułgaria, Litwa i Rumunia. Warto zauważyć, iż najsłabsze wahania zatrudnienia $\mathrm{w}$ analizowanym okresie wystąpiły w Czechach, na Węgrzech i w Słowenii, które to państwa charakteryzowały się pośrednimi udziałami umów na czas określony, odpowiednio na poziomie: 9,7\%, 10,8\% oraz 16,5\% w 2014 roku. Uzyskane wyniki analizy statystycznej mogą zatem potwierdzać istnienie U-kształtnej zależności pomiędzy udziałem umów na czas określony w liczbie pracujących ogółem a poziomem elastyczności zatrudnienia. 


\section{Elastyczność zatrudnienia w nowych krajach członkowskich Unii Europejskiej w latach 2000-2014 - wyniki analiz ekonometrycznych}

Wysunięte w poprzednich częściach niniejszego opracowania hipotezy odnoszące się do wpływu elastyczności zatrudnienia, płac realnych, czasu pracy oraz czynników instytucjonalnych na charakter dopasowań obserwowanych na rynku pracy zostały poddane weryfikacji z wykorzystaniem metod panelowych. Model estymowano na danych statystycznych dla 13 nowych krajów członkowskich Unii Europejskiej. Wykorzystano dane w ujęciu kwartalnym, pochodzące $\mathrm{z}$ internetowej bazy danych Eurostat (http://ec.europa.eu/eurostat/data/database) z okresu I kw. 2000 - IV kw. 2014. Dane zostały odsezonowane przy pomocy metody X12 ARIMA. Ze względu na brak niektórych danych lub brak wystarczająco długich szeregów czasowych zakres próby został skrócony w przypadku części krajów.

Model ekonometryczny został oparty na tradycyjnej funkcji popytu na pracę, w której uwzględnione zostały zarówno klasyczne, jak i keynesistowskie determinanty zatrudnienia, tj. produkcja oraz płace realne i długość czasu pracy. Model ten możemy zapisać równaniem postaci:

$$
\ln \left(Z_{i, t}\right)=\beta_{1} \ln \left(\mathrm{PKB}_{\mathrm{i}, \mathrm{t}}\right)+\beta_{2} \ln \left(\mathrm{RWage}_{\mathrm{i}, \mathrm{t}}\right)+\beta_{3} \ln \left(\mathrm{WTime}_{\mathrm{i}, \mathrm{t}}\right),
$$

gdzie: $Z_{i, t}$ - liczba pracujących wg BAEL (LFS) w kraju $i$ w okresie $t$, $P K B_{i, t}$ - rozmiary PKB w kraju $i \mathrm{w}$ okresie $t$, $R W_{i g} e_{i, t}$ - wysokość płac realnych w kraju $i$ w okresie $t$, WTime $e_{i, t}$ - przeciętna liczba godzin pracy w tygodniu w kraju $i$ w okresie $t$.

W celu weryfikacji hipotezy o wpływie czynników o charakterze instytucjonalnym na zakres i tempo dostosowań zatrudnienia, do modelu wprowadzono zmienne interakcyjne opisujące wpływ zmian udziału umów o pracę na czas określony w liczbie umów o pracę ogółem na elastyczność zatrudnienia względem PKB, płac realnych i czasu pracy. W przypadku pierwszej z nich uwzględniono nieliniowy charakter tej relacji. W przypadku pozostałych przyjęto, że zależność ma charakter liniowy.

Model wykorzystywany w badaniu empirycznym przyjął zatem postać4:

$$
\begin{aligned}
\ln \left(\mathrm{Z}_{\mathrm{i}, \mathrm{t}}\right)= & \beta_{1} \ln \left(\mathrm{PKB}_{\mathrm{i}, \mathrm{t}}\right)+\beta_{2} \ln \left(\mathrm{RWage}_{\mathrm{i}, \mathrm{t}}\right)+\beta_{3} \ln \left(\mathrm{WTime}_{\mathrm{i}, \mathrm{t}}\right)+\gamma_{1} \ln \left(\mathrm{PKB}_{\mathrm{i}, \mathrm{t}}\right) \cdot \mathrm{Uokr}_{\mathrm{i}, \mathrm{t}}+ \\
& \gamma_{2} \ln \left(\mathrm{PKB}_{\mathrm{i}, \mathrm{t}}\right) \cdot \mathrm{Uokr}_{\mathrm{i}, \mathrm{t}}^{2}+\gamma_{3} \ln \left(\mathrm{RWage}_{\mathrm{i}, \mathrm{t}}\right) \cdot \mathrm{Uokr}_{\mathrm{i}, \mathrm{t}}+\gamma_{4} \ln \left(\mathrm{WTime}_{\mathrm{i}, \mathrm{t}}\right) \cdot \mathrm{Uokr}_{\mathrm{i}, \mathrm{t}}
\end{aligned}
$$

${ }^{4}$ Model ten jest rozwinięciem modelu wykorzystanego w pracach: Kwiatkowski, Włodarczyk (2012) oraz Kwiatkowski, Włodarczyk (2014). 
gdzie: $U o k r_{i, t}-$ udział osób zatrudnionych na czas określony w liczbie pracujących ogółem w kraju $i$ w okresie $t$.

Dla uniknięcia niestacjonarności wykorzystywanych w modelu zmiennych, co mogłoby skutkować wystąpieniem tzw. regresji pozornej, model został przekształcony do postaci opartej na pierwszych przyrostach:

$$
\begin{aligned}
& \Delta \ln \left(\mathrm{Z}_{\mathrm{i}, \mathrm{t}}\right)=\beta_{1} \Delta \ln \left(\mathrm{PKB}_{\mathrm{i}, \mathrm{t}}\right)+\beta_{2} \Delta \ln \left(\mathrm{RWage}_{\mathrm{i}, \mathrm{t}}\right)+\beta_{3} \ln \left(\mathrm{WTime}_{\mathrm{i}, \mathrm{t}}\right)+ \\
& +\gamma_{1}\left[\Delta \ln \left(\mathrm{PKB}_{\mathrm{i}, \mathrm{t}}\right) \cdot \mathrm{Uokr}_{\mathrm{i}, \mathrm{t}}+\ln \left(\mathrm{PKB}_{\mathrm{i}, \mathrm{t}}\right) \cdot \Delta \mathrm{Uokr}_{\mathrm{i}, \mathrm{t}}\right]+ \\
& +\gamma_{2}\left[\Delta \ln \left(\mathrm{PKB}_{\mathrm{i}, \mathrm{t}}\right) \cdot \mathrm{Uokr}_{\mathrm{i}, \mathrm{t}}^{2}+\ln \left(\mathrm{PKB}_{\mathrm{i}, \mathrm{t}}\right) \cdot \Delta \mathrm{Uokr}_{\mathrm{i}, \mathrm{t}}^{2}\right]+ \\
& +\gamma_{3}\left[\Delta \ln \left(R W a g e_{i, \mathrm{t}}\right) \cdot \mathrm{Uokr}_{\mathrm{i}, \mathrm{t}}+\ln \left(\text { RWage }_{\mathrm{i}, \mathrm{t}}\right) \cdot \Delta \mathrm{Uokr}_{\mathrm{i}, \mathrm{t}}\right]+ \\
& +\gamma_{4}\left[\Delta \ln \left(\text { WTime }_{\mathrm{i}, \mathrm{t}}\right) \cdot \mathrm{Uokr}_{\mathrm{i}, \mathrm{t}}+\ln \left(\text { WTime }_{i, \mathrm{t}}\right) \cdot \Delta \mathrm{Uokr}_{\mathrm{i}, \mathrm{t}}\right] .
\end{aligned}
$$

W proponowanym modelu empirycznym parametry $\beta_{1}, \beta_{2} i \beta_{3}$ mają interpretację elastycznościową i informują nas, o ile punktów procentowych wzrośnie/ zmaleje zatrudnienie, jeżeli $\mathrm{PKB} /$ płace realne/przeciętny czas pracy wzrosną/zmaleją o 1 punkt procentowy. Parametry $\gamma_{1}, \gamma_{2}, \gamma_{3}$ i $\gamma_{4}$ mają natomiast charakter interakcyjny. Parametry $\gamma_{1}$ i $\gamma_{2}$ informują o tym, o ile punktów procentowych wzrośnie/ zmaleje elastyczność zatrudnienia względem PKB, jeżeli udział liczby pracujących na czas określony w liczbie pracujących ogółem wzrośnie/zmaleje o 1. Parametry $\gamma_{1}$ i $\gamma_{2}$ posiadają interpretację łączną. Parametry $\gamma_{3}$ i $\gamma_{4}$ informują o tym, o ile punktów procentowych wzrośnie/zmaleje elastyczność zatrudnienia względem płac realnych/czasu pracy, jeżeli udział liczby pracujących na czas określony w liczbie pracujących ogółem wzrośnie/zmaleje o 1.

W oparciu o rozważania teoretyczne przedstawione w części trzeciej możemy sformułować następujące oczekiwania dotyczące pożądanego znaku oszacowań parametrów modelu:

1) zgodnie $z$ teorią keynesowską uzasadnione jest oczekiwanie istnienia dodatniej zależności pomiędzy zatrudnieniem a rozmiarami agregatowego popytu oraz produkcji; oszacowanie parametru $\beta_{1}$ powinno być zatem dodatnie;

2) teoria neoklasyczna wskazuje na istnienie ujemnej zależności pomiędzy poziomem zatrudnienia a wysokością płac realnych, co powinno skutkować ujemnym oszacowaniem parametru $\beta_{2}$; na gruncie tej teorii należy również oczekiwać ujemnej zależności pomiędzy czasem pracy a poziomem zatrudnienia; oszacowanie parametru $\beta_{3}$ powinno być zatem ujemne;

3) potwierdzenie hipotezy o istnieniu nieliniowej zależności pomiędzy udziałem zatrudnienia na czas określony a elastycznością zatrudnienia względem PKB nastąpi w przypadku uzyskania ujemnej wartości oszacowania parametru $\gamma_{1}$ i dodatniej wartości oszacowania parametru $\gamma_{2}$;

4) potwierdzenie hipotezy o istotnym statystycznie wpływie udziału zatrudnienia na czas określony na elastyczność zatrudnienia względem płac realnych 
i czasu pracy nastąpi w przypadku uzyskania ujemnej wartości oszacowania parametru $\gamma_{3}$ i ujemnego oszacowania parametru $\gamma_{4}$.

Do modelu wprowadzono opóźnienia zmiennych objaśniających, uzyskując stosunkowo bogate rozkłady opóźnien. Opóźnienia poszczególnych zmiennych objaśniających dobierano zgodnie z zasadą „od ogółu do szczegółu” rozpoczynając od opóźnienia wynoszącego 4 okresy. Uwzględnienie opóźnień spowodowało skrócenie efektywnej próby modelu do okresu II kw. 2002 - IV kw. 2014. W modelu uwzględniono fakt, iż w analizowanym okresie wszystkie badane kraje przystąpiły do Unii Europejskiej. W tym celu wykorzystano zmienną zerojedynkową, która przyjmuje wartości 0 dla okresu przed akcesją i 1 dla okresu po wejściu do UE. Do modeli wprowadzono również zmienne zerojedynkowe dla obserwacji odstających, w celu poprawy dopasowań.

Model estymowano przy użyciu 4 różnych metod ekonometrycznych w celu zbadania odporności uzyskanych wyników na dobór metody estymacji i założeń dotyczących charakteru występujących w danych efektów przekrojowych. Wykorzystano panelową metodę najmniejszych kwadratów (Panel Ordinary Least Squares - Panel OLS). Model estymowano panelową MNK przy założeniu braku występowania efektów przekrojowych, z efektami przekrojowymi o charakterze stałym (fixedeffects - FE), z efektami o charakterze stałym i błędami standardowymi uzyskanymi metodą White'a (Fixed Effects White Standard Errors - FE (White SE), a także z efektami o charakterze stałym i korektą PCSE (Panel Corected Standard Errors), która pozwala na uchylenie założenia o homoskedastyczności, braku autokorelacji składnika losowego oraz braku korelacji składnika losowego pomiędzy jednostkami.

W tabeli 2 prezentujemy tzw. mnożniki długookresowe modelu, które informują nas o łącznym wpływie wywieranym przez zmienne objaśniające na zmienną objaśnianą. Wszystkie uzyskane oszacowania modelu charakteryzują się bardzo wysokim poziomem dopasowania mierzonym z wykorzystaniem współczynnika $\mathrm{R}^{2}$ - na poziomie powyżej $91 \%$. Uzyskane oszacowania charakteryzują się również normalnością rozkładu reszt, którą testowano przy pomocy testy Jarque’a-Bery. Uzyskano również dopuszczalne wartości statystyki Durbina-Watsona.

Analizując wyniki weryfikacji ekonometrycznej hipotez wysuniętych na podstawie przedstawionych wcześniej rozważań teoretycznych w grupie NKC w latach 2000-2014, stwierdzamy, że wszystkie zaproponowane przez nas zmienne objaśniające, czyli PKB, płace realne oraz przeciętna długość czasu pracy w tygodniu, były istotnymi determinantami zatrudnienia w tym okresie. Uzyskane oszacowania parametrów i długookresowe mnożniki opisujące wpływ zmiennych objaśniających na elastyczność zatrudnienia pozwalają stwierdzić, iż wzrost rozmiarów PKB przekładał się na wzrost zatrudnienia, a wzrost płac realnych powodował jego spadek. Zaskakującym z punktu widzenia teorii dostosowań na rynku pracy może być natomiast znak parametru długookresowego opisującego wpływ czasu pracy na rozmiary zatrudnie- 
nia, który okazał się dodatni. Z teorii ekonomicznej wynika, iż w przypadku wzrostu przeciętnego czasu pracy należałoby oczekiwać raczej spadków zatrudnienia. Fakt uzyskania odmiennego niż wynikający z teorii ekonomii znaku oszacowania można jednak w przypadku analizowanej grupy krajów wytłumaczyć tym, iż podlegają one cały czas procesom związanym $\mathrm{z}$ transformacją ich gospodarek, a tym samym z racjonalizacją zatrudnienia w przedsiębiorstwach. W takim przypadku możliwe jest jednoczesne występowanie ograniczeń czasu pracy i spadków zatrudnienia.

Tabela 2. Oszacowania mnożników długookresowych modelu ekonometrycznego dla NKC w okresie I kw. 2000 - IV kw. 2014

\begin{tabular}{|l|c|c|c|c|}
\hline \multicolumn{1}{|c|}{ Metoda estymacji } & OLS & FE & FE (White SE) & FE (PCSE) \\
\hline Liczba krajów & 13 & 13 & 13 & 13 \\
\hline Liczba obs. & 663 & 663 & 663 & 663 \\
\hline Zmienna zal. & $\Delta \ln Z$ & $\Delta \ln Z$ & $\Delta \ln Z$ & $\Delta \ln Z$ \\
\hline$\Delta \ln$ PKB & 1.23 & 1.09 & 1.38 & 1.65 \\
\hline$\Delta \ln$ PKB*Uokr & -0.017 & -0.02 & -0.019 & -0.018 \\
\hline$\Delta \ln$ PKB*Uokr ${ }^{2}$ & - & - & - & - \\
\hline$\Delta \ln$ RWage & -0.059 & -0.008 & -0.117 & -0.015 \\
\hline$\Delta \ln$ RWage*Uokr & -0.015 & -0.026 & -0.012 & -0.011 \\
\hline$\Delta \ln W T i m e$ & 2.48 & 4.27 & 2.19 & 2.03 \\
\hline$\Delta \ln W T i m e * U o k r$ & 0.024 & 0.039 & 0.02 & 0.017 \\
\hline Adj. R ${ }^{2}$ & 0.93 & 0.91 & 0.96 & 0.96 \\
\hline Durbin-Watson & 1.96 & 2.04 & 1.77 & 1.77 \\
\hline $\begin{array}{l}\text { Test Jarque'a-Bery } \\
\text { (wartość } p \text { ) }\end{array}$ & 0.53 & 0.23 & 0.59 & 0.52 \\
\hline
\end{tabular}

Źródło: Obliczenia własne przy pomocy programu EViews 8

Analizując wartości uzyskanych oszacowań mnożników długookresowych, zauważamy, że w przypadku wszystkich metod estymacji elastyczność zatrudnienia względem zmian PKB jest wyższa niż 1, co oznacza, iż zmiany zatrudnienia spowodowane impulsem popytowym prowadzą do dalszych mnożnikowych zmian agregatowego popytu i wzrostów zatrudnienia. Na uwagę zasługuje fakt bardzo niskiej elastyczności zatrudnienia względem płac realnych, co może oznaczać, iż w analizowanej grupie krajów dominują dostosowania ilościowe zatrudnienia. Bardzo silny skumulowany wpływ zmian czasu pracy na poziom zatrudnienia można natomiast tłumaczyć dużym nasileniem procesów transformacji gospodarek badanych krajów.

Wykorzystanie zmiennych interakcyjnych pozwoliło na weryfikację hipotez o wpływie rodzajów umów o pracę na elastyczność zatrudnienia względem jego determinantów. Ujemny znak oszacowania przy parametrze długookresowym opisującym wpływ rodzaju umów na elastyczność zatrudnienia względem PKB oznacza, iż wzrost udziału umów na czas określony prowadzi do spadku tej elastycz- 
ności. Ujemny znak oszacowania parametru opisującego wpływ rodzaju umów na elastyczność zatrudnienia względem płac i dodatni znak oszacowania parametru dotyczącego wpływu rodzaju umów na elastyczność zatrudnienia względem czasu pracy oznaczają natomiast, iż wzrost udziału umów na czas określony w liczbie umów o pracę ogółem prowadzi do wzrostu elastyczności zatrudnienia względem tych zmiennych. Potwierdza to hipotezę mówiącą o wymienności pomiędzy dostosowaniami ilościowymi zatrudnienia a dostosowaniami w zakresie płac i czasu pracy. Analizując wartości uzyskanych oszacowań, należy również zauważyć, iż wartości długookresowych parametrów interakcyjnych są bardzo małe w porównaniu do wartości skumulowanych elastyczności zatrudnienia. Jedynie w przypadku płac realnych zmiana elastyczności będąca wynikiem wzrostu udziału umów na czas określony jest zauważalna w porównaniu z wyjściowym oszacowaniem elastyczności.

Wyniki weryfikacji empirycznej wskazują, że nie udało się potwierdzić hipotezy o istnieniu U-kształtnej zależności pomiędzy elastycznością zatrudnienia a udziałem umów na czas określony w ogólnej liczbie umów o pracę. Uzyskane w tym zakresie oszacowania były nieistotne statystycznie.

\section{Wnioski}

Procesy dostosowawcze na rynku pracy są skutkiem powstania rozbieżności między istniejącym popytem na siłę roboczą a popytem pożądanym wynikającym z obniżonych rozmiarów produkcji. Dostosowania te mogą przybrać różną formę. Mogą wystąpić tendencje do obniżki płac, co jest silnie eksponowane w teoriach utrzymanych w tradycji neoklasycznej. Przedsiębiorcy mogą też próbować obniżyć koszty działalności poprzez zmniejszenie czasu pracy zatrudnionych pracowników, jeśli redukcja czasu pracy wiąże się z redukcją kosztów pracy. Mogą również wystąpić dostosowania w postaci zmniejszenia liczby pracowników, silnie eksponowane w ekonomii keynesistowskiej. Dostosowania te są tym większe, im wyższa jest elastyczność zatrudnienia względem wymienionych czynników.

Problem elastyczności zatrudnienia oraz szerszego pojęcia, jakim jest elastyczność rynku pracy, był wielokrotnie podejmowany w teoriach ekonomicznych, ale warto zauważyć, że w sposób dosyć jednostronny. Dostrzegano przede wszystkim dobroczynne właściwości elastyczności rynku pracy sprzyjające powstawaniu pożądanych stanów w gospodarce. Nie dostrzegano natomiast negatywnych konsekwencji wyższej elastyczności rynku pracy. Było to prawdopodobnie wynikiem koncentracji na ekonomicznych aspektach procesów gospodarczych oraz pomijania aspektów społecznych. Uwzględnienie tych aspektów ukazuje wpływ wyższej elastyczności rynku pracy na silniejsze wahania dochodów i wahania zatrudnienia, które z perspektywy pracowników nie mogą być ocenione korzystnie. 
Ważną rolę w kształtowaniu elastyczności zatrudnienia odgrywa struktura zatrudnienia według rodzaju umów o pracę, tj. umów na czas nieokreślony i czas określony. Argumenty teoretyczne i obserwacje empiryczne pozwalają sformułować hipotezę o U-kształtnej zależności między udziałem pracujących na umowach na czas określony w ogólnej liczbie pracujących a elastycznością zatrudnienia. Należy również oczekiwać zwiększenia elastyczności płac i czasu pracy na skutek wzrostu udziału umów na czas określony, co może się przekładać na wzrost elastyczności zatrudnienia względem płac i czasu pracy.

Przeprowadzona analiza statystyczna pozwoliła stwierdzić, że w latach 20002014 w nowych krajach członkowskich Unii Europejskiej obserwowano zróżnicowane zmiany poziomu zatrudnienia. Zdecydowanie wyższa cykliczna zmienność zatrudnienia wystąpiła w krajach o stosunkowo wysokim i stosunkowo niskim udziale umów na czas określony w liczbie umów o pracę ogółem. Najmniejszą zmienność zatrudnienia w badanym okresie obserwowano natomiast w krajach o średnim udziale tych umów, takich jak Czechy czy Węgry.

Wyniki estymacji modelu panelowego dla 13 nowych krajów członkowskich Unii Europejskiej w latach 2000-2014 potwierdzają hipotezę o wpływie rodzaju umów o pracę na elastyczność zatrudnienia. W szczególności wzrost udziału umów na czas określony prowadzi do spadku elastyczności zatrudnienia względem PKB oraz do wzrostu elastyczności zatrudnienia względem płac realnych i czasu pracy. Wyniki te potwierdzają tym samym hipotezę o wymienności dostosowań zatrudnienia oraz płac i czasu pracy. W sytuacji gdy możliwe jest stosunkowo swobodne stosowanie przez pracodawców umów na czas określony, mają oni większe możliwości reakcji na zmiany koniunktury gospodarczej poprzez dostosowania czasu pracy i płac realnych, co sprawia, że odkładają na później ewentualne dostosowania ilościowe zatrudnienia.

Uzyskane wyniki weryfikacji empirycznej nie pozwalają natomiast potwierdzić hipotezy o istnieniu U-kształtnej zależności pomiędzy elastycznością zatrudnienia a udziałem umów na czas określony w ogólnej liczbie umów o pracę.

\section{Bibliografia}

Adnett N. (1996), European Labour Market. Analysis and Policy, Longman, London.

Aguirregabiria V., Allonso-Borrego C. (2014), Labor Contracts and Flexibility: Evidence From a Labor Market Reform in Spain, „Economic Inquiry”, vol. 52, no. 2, s. 930-957.

Arellano M., Bover O. (1995), Another Look at the Instrumental Variables Estimation of Error-components Models, „Journal of Econometrics”, vol. 68, no. 1, s. 29-51.

Bednarski M. (2012), Zatrudnienie na czas określony. Perspektywa pracodawców, [w:] M. Bednarski, K.W. Frieske (red.), Zatrudnienie na czas określony w polskiej gospodarce. Społeczne i ekonomiczne konsekwencje zjawiska, Instytut Pracy i Spraw Socjalnych, Warszawa. 
Benito A., Hernando I. (2008), Labour Demand, Flexible Contracts and Financial Factors: Firm-Level Evidence from Spain, „Oxford Bulletin of Economics and Statistics”, vol. 70, no. 3, s. 283-301.

Bentolila S., Cachuc P., Dolado J.J., Le Barbanchon T. (2012), Two-Tier Labour Markets in the Great Recession: France versus Spain, „Economic Journal”, vol. 122, no. 562, s. F155-F187.

Blanchard O.J., Landier A. (2002), The Perverse Effects of Partial Labor Market Reform: Fixed Duration Contracts in France, „Economic Journal”, vol. 112, no. 480, s. F214-F244.

Boeri T., Ours J. van (2011), Ekonomia niedoskonatych rynków pracy, Wolters Kluwer Polska, Warszawa.

Bosworth D.L., Dawkins P., Stromback T. (1996), The Economics of the Labour Market, Longman, London.

Cahuc P., Zylberberg A. (2004), Labor Economics, The MIT Press, Cambridge-MassachusettsLondon.

Cazes S., Laiglesia J.R. de (2014), Temporary Contracts, Labour Market Segmentation and Wage Inequality, conference paper.

Dhyne E., Mahy B. (2009), The use of fixed-term contracts and the labour adjustment in Belgium, „NBB Working Paper”, no. 169.

Ehrenberg R.G., Smith R.S. (2012), Modern Labor Economics: Theory and Public Policy, Prentice Hall, Upper Saddle River, New Jersey.

Friedman M. (1975), Rola polityki pieniężnej, [w:] A. Szeworski (opr.), Teoria i polityka stabilizacji koniunktury. Wybór tekstów, PWE, Warszawa.

Gebel M. (2009), Fixed-Term Contracts at Labour Market Entry in West Germany: Implications for Job Search and First Job Quality, „European Sociological Review”, vol. 25, no. 6, s. 661-675.

Goux D., Maurin E., Pauchet M. (2001), Fixed-term contracts and the dynamics of labour demand, „European Economic Review”, vol. 45, no. 3, s. 533-552.

Jeleniewska J., Chrościelewski R., Opieka R. (2008), Korzyści i zagrożenia dla pracowników ze stosowania elastycznych form zatrudnienia na bazie doświadczeń NSZZ „, Solidarność” Stoczni Gdańskiej, [w:] C. Sadowska-Snarska (red.), Elastyczne formy pracy-szanse i zagrożenia, Wyższa Szkoła Ekonomiczna w Białymstoku, Białystok.

Haberler G. (1947), The General Theory, [w:] S. E. Harris (red.), The New Economics, A.A. Knopf, New York.

Keynes J.M. (1985), Ogólna teoria zatrudnienia, procentu i pieniadza, PWN, Warszawa.

Kryńska E. (2001), Dylematy polskiego rynku pracy, Instytut Pracy i Spraw Socjalnych, Warszawa.

Kwiatkowski E. (2006), Bezrobocie. Podstawy teoretyczne, Wydawnictwo Naukowe PWN, Warszawa.

Kwiatkowski E., Włodarczyk P. (2012), Wpływ prawnej ochrony zatrudnienia na rynek pracy $w$ warunkach negatywnego szoku ekonomicznego, „Gospodarka Narodowa”, vol. LXXX/ XXI, nr 11-12, s. 1-23.

Kwiatkowski E., Włodarczyk P. (2014), Importance of Employment Protection and Types of Employment Contracts for Elasticity of Employment in the OECD Countries, „Comparative Economic Research", vol. 17, no. 1, s. 21-44.

Lancker W. van (2012), The European World of Temporary Employment. Gendered and Poor?, „European Societies”, vol. 14, no. 1, s. 83-111.

Layard R. (1986), How to Beat Unemployment, Oxford University Press, Oxford.

Layard R., Nickell S., Jackman R. (1991), Unemployment: Macroeconomic Performance and the Labour Market, Oxford University Press, Oxford.

Malul M., Rosenboim M., Shavit T., Tarba S.Y. (2011), The Role of Employment Protection During An Exogenous Shock to An Economy, „World Economy”, vol. 11, no. 2, s. 1-12. 
Modigliani F. (1944), Liquidity Preference and the Theory of Interest and Money, „Econometrica”, styczeń, [przedruk w:] H. Hazlitt (red.) (1960), The Critics of Keynesian Economics, D. van Nostrand Co. Inc., Princeton-New York.

Ortega B., Marchante A.J. (2010), Temporary contracts and labour productivity in Spain: a sectoral analysis, „Journal of Productivity Analysis”, vol. 34, no. 3, s. 199-212.

Pfeiffer C. (2009), Fixed-term Contracts and Employment Adjustment: An Empirical Test of the Core - Periphery Hypothesis Using German Establishment Data, „Economic Record”, vol. 85, no. 268 , s. 92-107.

Pigou A.C. (1933), The Theory of Unemployment, Macmillan and Co. Ltd., London.

Rogut A. (2008), Determinanty popytu na prace w Polsce w okresie transformacji, Wydawnictwo Uniwersytetu Łódzkiego, Łódź.

Samuelson P.A. (1979), Economics, Macmillan, London.

Smith A. (1954), Badania nad natura i przyczynami bogactwa narodów, PWN, Warszawa.

Smith S. (2003), Labour Economics, Routledge, London.

Solow R.M. (1998), What is Labour Market Flexibility? What is it Good For?, „Proceedings of the British Academy", vol. 97.

Tsoulfidis L. (2010), Competing Schools of Economic Thought, Springer Verlag, Berlin-Heidelberg.

Wincenciak L., Zys M. (2013), Determinanty nietypowych form zatrudnienia absolwentów w Polsce, „Gospodarka Narodowa”, vol. LXXXIII/XXIV, nr 9, s. 117-138.

\title{
Types of employment contracts and elasticity of employment in the European Union new member states in 2000-2014
}

\begin{abstract}
The article is focused on the problem of elasticity of employment in the economies of the European Union new member states in 2000-2014. Special attention is given to the role of types of employment contracts and their influence on the elasticity of employment. Theoretical arguments and empirical observations enable us to formulate hypothesis about a U-shaped relationship between the share of fixed-term employment in total employment and elasticity of employment in a given economy. We should also expect increases of price and working time elasticity in response to increases in the share of fixed-term employment. Results of panel model estimations performed using the data for 13 new European Union member states in 2000-2014 confirm the hypothesis about an impact of share of fixed-term employment in total employment on the elasticity of employment. In particular, an increase in the number of fixed-term contracts results in the fall of elasticity of employment with respect to GDP and increase in the elasticity of employment with respect to real wages and working time. There is however no confirmation of the hypothesis concerning a U-shaped relationship between elasticity of employment with respect to GDP and the share of fixed-term emplyment.
\end{abstract}

Keywords: types of employment contracts, elasticity of employment, GDP, real wages

JEL: J23, J41

\begin{tabular}{|l|l|}
\hline \multirow{2}{*}{ OPEN ACCESS } & $\begin{array}{l}\text { C by the author, licensee Łódź University - Łódź University Press, Łódź, Poland. } \\
\text { This article is an open access article distributed under the terms and conditions } \\
\text { of the Creative Commons Attribution license C(-BY } \\
\text { (http://creativecommons.org/licenses/by/3.0/) }\end{array}$ \\
\cline { 2 - 2 } \\
Received: 2016-10-24; verified: 2016-12-05. Accepted: 2017-02-15
\end{tabular}

